\title{
Chromatographic Separation and Identification of Many Fatty acids and Phenolic Compounds from Flowers of Celosia cristata L. and Its Inhibitory Effect on Some Pathogenic Bacteria
}

\author{
Fatimah I. Sultan \\ Northern Technical University, Technical Agricultural College, Mosul, Iraq
}

Correspondence Author: Fatimah I. Sultan, Northern Technical University, Technical Agricultural College, Mosul / Iraq. E-mail: i_education@yahoo.com

Received date: 15 April 2018, Accepted date: 15 June 2018, Online date: 5 July 2018

Copyright: (C) 2018 Fatimah I. Sultan. This is an open-access article distributed under the terms of the Creative Commons Attribution License, which permits unrestricted use, distribution, and reproduction in any medium, provided the original author and source are credited.

\begin{abstract}
The active constituents were separated from the flowers of Celosia cristata L. using column chromatography (CC) and solvent system of (chloroform-ethanol) from (Acetone, Ethanol and also Aqueous extracts). Moreover saponification process was carried out to get liberated of many fatty acid compounds. GLC-analysis was identified of four fatty acids (Heptanoic, Octanoic, Lauric and Palmitic acids). Also, acid hydrolysis was achieved to get many free pole of phenolic compounds which were identified as (Hydroquinone, p-Hydroxybenzoic acid, Coumarin, Salicylic acid and Thymol by using HPLC analysis. Fatty acids and Phenolic compounds were confirmed by using authentic samples for comparison. The active separated compounds (fatty acids and phenolic compounds) showed different effect against the micro-organism (m.o) under study by using disc diffusion method turbidity.
\end{abstract}

Key words: GLC analysis, Celosia cristata, Fatty acids, HPLC analysis, Phenolic compounds, Antibacterial activities.

\section{INTRODUCTION}

Celosia cristata (Celosia in Greek means burning) is a member of the genus celosia, and is commonly known as cockscomb, since the flower looks like the head on a rooster (cock). It is called chi kaun in china. It belongs to the class magnoliopsida, order caryophyllales and family Amaranthaceae. Number of plants from the family are known for their vibrant colored infloresence and thus as an ornamental plant. Besides developing landscape plenty medicinal qualities are also known from the plant with promising activity (Surse, et al., 2013). For description, it is non woody plant, grows 5 to 2 feet in height, it is also grown commonly in Africa, south America, India and some parts of Asia (Rubini, et al., 2012). Also, for phytochemical constituents, Celosia cristata mainly contains flavonoids, cochliophilin, isoflavone, and cristatein (5-Hydroxy-6-hydroxymethyl-7,2-dimethoxyisoflavone) (Surse, et al., 2013). Plant leaves contains two glycoproteins ccp and ccp-27 at the flowering stage (Balasubrahmanyam, et al., 2000).Pure celosianins i-e- amaranthine type of betacyanins like celosianin I, celosianin II and their C-15 epimers isolated from Celosia cristata inflorescence (Cai, et al., 2003). Plant seeds contain 4-hydroxy phenethyl alcohol, kaempferol, quercetin, $\beta$-sitosterol, 2-hydroxy octadecenoic acid, stigmasterol, saponins such as cristanin, celosin A, celosin B, celosin C and celosin D (Xiang, et al., 2010).

Betalains and antioxidant, the different betalains from amaranthaceae family showed strong antioxidant activity when evaluated using DPPH assay. Their activities were discussed in relation to their structure. Thus natural colorants from Amaranthaceae family can also be used as natural antioxidants (Cai, et al., 2003).For anthelmintic activity, Aqueous, methanolic and chloroform extracts of Celosia cristata leaves were also investigated. Adult worms of pheretima posthuma, were used as it shows resemblance with intestinal roundworm parasites anatomically and physiologically. Chloroform extract showed no significant activity. Observations of time for paralysis and time for death were used to assess significant activity. Aqueous extract showed more significant activity than methanolic extract (Rubini, et al., 2012).For impact on adipogenesis, the impact extract of Celosia cristata flowering top on adipogenic potential inactive human adipose tissue progenitor cells was evaluated. It was revealed that the extract has a capacity to decrease lipid content of progenitor cells undergoing differentiation. Adipogenesis was studied at the level expression of genus which are involved in adipogenesis. Promising results were found and can be used for the treatment of obesity (Fitoussi, et al., 2013).

Traditional knowledge of the plants provides widely accepted natural phytoconstituents for treatment of various ailments, preliminary phytochemical evaluation revealed presence of flavonoids, carbohydrates, saponin, sterols, proteins and amino acids (Surse, et al., 2014). By phytochemical evaluation, the whole plant powder was also subjected for successive soxhlet extraction by using solvents like pet.ether, chloroform, ethanol, and water to obtain extracts, these extracts were then used for phytochemical evaluation and also various chemical tests were conducted to detect the presence of phytoconstituents like carbohydrates, proteins, amino acids, saponins, flavonoids and phenolic substances (Surse, et al., 2014; Harborne, 1998).

Celosia cristata flowers showed antioxidant properties and also antimicrobial effect. It also had sun protection effects (Jayanthy and Shafna, 2012).

The antimicrobial properties of ethanolic, methanolic and other solvent extracts of Celosia cristata L., was evaluated against various microorganisms, Staphylococcus aureus, Escherichia coli, Pseudomonas aeruginosa, Bacillus subtillus, Salmonella typhimurium and Candida albicans. The minimal inhibitory concentration (MIC) values in the range of 0.125 to $1 \mathrm{mg} / \mathrm{ml}$ hexane fractions of methanolic and ethanolic extracts exhibited good activity against (0.5 mg/ml) and Candida albicans $(1 \mathrm{mg} / 1 \mathrm{ml})$ and dichloromethane fraction showed similar results (Yun, et al., 2008).

\section{MATERIAL AND METHODS}

Celosia cristata flower sample were preparation which flowers packed bags was acquired from home garden in Mosul - Iraq and also classified by Dr. Talal Taha (a director of the medical plant project in the Mosul Dam project). The material was cleaned, dried and grinded. 
Citation: Fatimah I. Sultan, Chromatographic Separation and Identification of Many Fatty acids and Phenolic Compounds from Flowers of Celosia cristata L. and Its Inhibitory Effect on Some Pathogenic Bacteria. Australian Journal of Basic and Applied Sciences, 12(7): 25-31.

Preparation of the plant extracts:

A batch of $50 \mathrm{gm}$ of the ground flowers of Celosia cristata was subjected to extraction by soxhlet apparatus for 6-8 hrs. with $1 \mathrm{~L}$ of three sequence solvents (pet. ether, acetone and ethanol), water was also used at room temperature as an aqueous solvent. All these extracts were concentrated to $25 \mathrm{ml}$ on a vacuum rotary evaporator at $50^{\circ} \mathrm{C}$ (Harborne, 1998). The crude material of each extract was used for further studies and analysis.

\section{Fractionation of Acetone, Ethanol and Aqueous crude extract:}

$300 \mathrm{mg}$ of each mentioned crude extracts which was previously prepared was mixed with a small amount of Silica gel ( $25 \mathrm{gm})$ and then transferred to the top of a prepared Silic gel (60-120 mesh) column. The column was eluted with (pet.ether: chloroform) with concentration of 10\% V/V intervals, followed with continuous elution with (chloroform: ethanol).

\section{Saponification of the extracts:}

Saponification process was carried out of pet.ether extract which was refered to $\left(\mathrm{C}_{1}\right)$ from acetone crude extract was fractionated to chloroform-ethanol to get $\left(\mathrm{C}_{3} \mathrm{~F}_{2}\right)$ and $\left(\mathrm{C}_{3} \mathrm{~F}_{3}\right)$. Moreover, the fraction of $\left(\mathrm{C}_{3} \mathrm{~F}_{2}\right)$ was also saponified to liberate free fatty acids, also acid hydrolysis was carried out for the fraction $\mathrm{C}_{3} \mathrm{~F}_{3}$ to obtain free poles of phenolic compounds. Also, the crude ethanolic extract was fractionated to (chloroform-ethanol) which was also obtained two fraction, the first fraction was also saponified to get $\mathrm{C}_{4} \mathrm{~F}_{2}$ and acid hydrolysis was carried out for the second fraction to get $\left(\mathrm{C}_{4}\right)$. Moreover, the aqueous crude extract was fractionated to (chloroform-ethanol) and after saponification was carried out to get $\mathrm{C}_{5} \mathrm{~F}_{1}$, and acid hydrolysis was carried out of other fraction to obtain $\mathrm{C}_{5}$.

\section{Alkaline hydrolysis to obtain fatty acid compounds:}

Pet.ether extracts and the fractions of (chloroform-ethanol) as a result from column chromatography. A mixture of 10 gm of each pet-ether extracts and also the fractions (chloroform-ethanol) from acetone, ethanol and aqueous extracts $\left(\mathrm{C}_{3} \mathrm{~F}_{2}, \mathrm{C}_{4} \mathrm{~F}_{2}, \mathrm{C}_{5} \mathrm{~F}_{1}\right)$ and $100 \mathrm{ml}$ of $7.5 \mathrm{M}$ of $\mathrm{KOH}$ in MeOH: water (3:2) was refluxed in a round bottom flask for $90 \mathrm{~min}$. at $100^{\circ} \mathrm{C}$. The suspension crude extract was allowed to cool down to room temperature, and $100 \mathrm{ml}$ of D.W was added. The crude was extracted with diethyl ether $(2 \times 100 \mathrm{ml})$ to remove unhydrolysed lipid. The hydrolyse was acidified with $20 \%$ (v/v) conc. $\mathrm{H}_{2} \mathrm{SO}_{4}$ up to pH=2. the liberate fatty acids was extracted with diethyl ether $(2 \times 100 \mathrm{ml})$. The combined extracts were washed with water and dried over anhydrous sodium sulfate, filtered and concentrated under vacuum to give $1.2 \mathrm{gm}$ of crude fatty acid compounds (Aruther, 1972).

\section{Preparation of Methyl Esters:}

$0.1 \mathrm{ml}$ of acetyl chloride was added to $25 \mathrm{ml}$ dry methanol with stirring. Also, a sample of $0.5 \mathrm{ml}$ of dry fatty acids were added to above mixture, then boiled under reflux in a water bath for $20 \mathrm{~min}$, in a dry closed system, cooled the used for analysis by GLC method (Al-Kaisy, et al., 1991).

\section{Acid hydrolysis to separate free pole of phenolic compounds:}

The fractions of (chloroform-ethanol) resulted from column chromatography. A mixture of $5 \mathrm{ml}$ of fraction (chloroform-ethanol) from acetone, ethanol and aqueous extracts $\mathrm{C}_{3} \mathrm{~F}_{3}, \mathrm{C}_{4} \mathrm{~F}_{3}, \mathrm{C}_{5} \mathrm{~F}_{2}$ and $25 \mathrm{ml}$ of $(1 \mathrm{~N}) \mathrm{HCl}$ was refluxed in a round bottom flask for $1 \mathrm{hrs}$ at $100^{\circ} \mathrm{C}$. The solution was transferred to the separating funnel after cooling and $(2 \times 15 \mathrm{ml})$ of ethol acetone was added with stirring and after isolation of organic layer from aqueous layer, the organic layer was dried by adding $10 \mathrm{gm}$ of magnesium sulfate for $10 \mathrm{~min}$. The ethyl acetate was concentrated under a vacuum rotary evaporator and then the free pole of phenolic compounds were kept in glass bottles for further analysis (Harborne, 1998).

\section{GLC-Analysis:}

The fatty acid methyl esters can be obtained either directly by transmethylation of the parent lipids by refluxing for 90 min. with $\left(\mathrm{MeOH}_{-}\right.$benzene $\left.\mathrm{H}_{2} \mathrm{SO}_{4}\right)$ (20:10:1) from the free acids by the acetyl chloride-methanol. The procedure, the esters were analysed by GLC on a Packurd 419 equipped with adanl flame ionization detectors held at $270^{\circ} \mathrm{C}$. A $(2.12 \mathrm{~m} \times 2 \mathrm{~mm})$. international diameter column packed with $3 \%$ silar $10^{\circ} \mathrm{C}$ on Gas chrom Q (100-120) $\mathrm{m}$ was held at initially, then raised at $5^{\circ} \mathrm{C} / 1 \mathrm{~min}$. to 20 . The identification of fatty acid was determined by references to a standard of known composition (John and Denis, 1980).

\section{HPLC-Analysis:}

The free pole of phenolic compounds was identified by using HPLC apparatus with ShimadzoLC-2010. AHT after purification by filters with the diameter of 0-1 micrometer, and using of $320 \mathrm{~nm}$ as wavelength and $1 \mathrm{ml} / \mathrm{min}$ flow rate and $\left(85 \%\right.$ Acetonitrile: $\left.15 \mathrm{H}_{2} \mathrm{O}\right)$ as a mobile phase by using the column of $\mathrm{C}_{18}(4 \times 240$ $\min )$ at $30^{\circ} \mathrm{C}$ temperature. The instrument was provided from a cherey company Naged and all measurements were carried out in the Laboratory of college education, University of Mosul.

\section{Antibacterial activities of prepared extract of Celosia cristata:}

The antibacterial effect of these extracts were tested on all studied bacteria according to the modified method of (Bauer, et al., 1966) in which the inoculums were prepared in nutrient broth and incubator at $37^{\circ} \mathrm{C}$ for $(18-24)$ hrs. The density of the tested suspensions was adjusted to that of the $0.5 \mathrm{McFarland}$ standard. Muller-Hinton agar plated was inoculated by dipping a sterile cotton swabs in the inoculums, the excess inoculums were removed by pressing and rotating the swabs firmly against the side of the tubes above the level of the liquids and the swabs were streaked all over the surface of application. Finally, the inoculums were left to dry for few minutes later $50 \mathrm{ml}$ of each of the prepared extracts were dried and re-dissolved in DMSO and placed on filter paper discs $6 \mathrm{~mm}$ in diameter which were done on the inoculated plates, the antibiotics discs were also placed. The plates were inoculated at $37^{\circ} \mathrm{C}$ for $(18-24) \mathrm{hrs}$. the diameter of each zone of inhibition (including the diameter of wells and discs) were measured, recorded and compared with that of the standard antibiotics (Gentamicin (CN) 10 meg, Amikacia (AK) $10 \mathrm{meg}$, Tobramycin (TOB) $10 \mathrm{meg}$ ). Also, we used various concentrations $(800-12.5) \mathrm{mg} / \mathrm{cm}^{3}$ of plant extracts under study. The extract that produced a zone of inhibition was further studied using different concentrations of this extract ranged from (800-12.5) $\mathrm{mg} / \mathrm{cm}^{3}$ (Adam, 2006).

\section{RESULTS AND DISCUSSION}

During the phytochemical screening and previous studies (Xiang, et al., 2010; Adam, 2006) of the Celosia cristata composition which were mentioned as many fatty acid compounds, and many of phenolic compounds that investigated of the flowers of Celosia cristata. By continuation of above work we have noticed and identified many fatty acid compounds by using GLC-analysis. The table (1) and Fig (1 and 2) were showed the presence of four fatty acid compounds. The table (1) was showed that fraction of $\mathrm{C}_{3} \mathrm{~F}_{2}$ was contained of Octanoic $(0.0034 \%)$, Lauric $(0.0013 \%)$ and Palmitic $(0.0019 \%)$ acids, while the fraction of $\mathrm{C}_{4} \mathrm{~F}_{2}$ was contained Heptanoic $(0.0093 \%)$, Octanoic $(0.0014 \%)$, Lauric $(0.0043 \%)$ and Palmitic $(0.0079 \%)$ acids. The fraction $\mathrm{C}_{5} \mathrm{~F}_{2}$ was also contained Heptanoic $(0.0035 \%)$, Octanoic $(0.028)$, Lauric $(0.004)$ and Palmitic $(0.0101 \%)$ acids.

From the table (1) which was indicating the fraction of $\mathrm{C}_{4} \mathrm{~F}_{2}$ was confirmed more lipid content Lauric which also named as omega-6 and played an important role in the body and it combined with omega-3- gave many health benefit (Asif, 2011).

Also, phenolic compounds were identified table (2) and Fig (3 and 4) showing the presence of many phenolic compounds in the flowers of Celosia cristata in the different extracts, so the $\mathrm{C}_{4}$ extract is contained in Hydroquinone (37.914\%) area and salicylic acid at (50.523\%) area. The other fractions which were carried out from the column and acid hydrolysis took place to release free phenolic compounds were occurred to get HPLC analysis which indicated as followings.

The fraction $\mathrm{C}_{3} \mathrm{~F}_{3}$ was contained Hydroquinone with $\mathrm{R}_{\mathrm{t}}(2.436 \mathrm{~min})$, $\mathrm{p}$-Hydroxybenzoic acid $\mathrm{R}_{\mathrm{t}}(2.863 \mathrm{~min})$ and Coumarin $\mathrm{R}_{\mathrm{t}}(3.103 \mathrm{~min})$, while the fraction $\mathrm{C}_{4} \mathrm{~F}_{3}$ was contained p-Hydroxybenzoic acid $\mathrm{R}_{\mathrm{t}}(2.853 \mathrm{~min})$ and Salicylic acid $\mathrm{R}_{\mathrm{t}}(2.403 \mathrm{~min})$.

Moreover, the fraction $\mathrm{C}_{5} \mathrm{~F}_{2}$ was also contained Hydroquinone $\mathrm{R}_{t}(2.501 \mathrm{~min})$, p-Hydroxybenzoic acid $\mathrm{R}_{t}(2.813 \mathrm{~min})$ and Thymol $\mathrm{R}_{t}(3.571)$. 
Citation: Fatimah I. Sultan, Chromatographic Separation and Identification of Many Fatty acids and Phenolic Compounds from Flowers of Celosia cristata L. and Its Inhibitory Effect on Some Pathogenic Bacteria. Australian Journal of Basic and Applied Sciences, 12(7): 25-31.

Table 1: GLC analysis of Celosia cristata extracts of fatty acid compounds.

\begin{tabular}{|c|c|c|c|c|c|c|c|c|}
\hline \multirow[t]{3}{*}{ Extracts of Celosia cristata } & \multicolumn{8}{|c|}{ Fatty acid compounds } \\
\hline & \multicolumn{2}{|c|}{ Heptanoic acid $6.925 \mathrm{~min}$} & \multicolumn{2}{|c|}{$\begin{array}{l}\text { Octanoic acid } \\
8.309 \mathrm{~min}\end{array}$} & \multicolumn{2}{|c|}{$\begin{array}{l}\text { Lauric acid } \\
12.573 \mathrm{~min}\end{array}$} & \multicolumn{2}{|c|}{$\begin{array}{l}\text { Palmitic acid } \\
15.99 \text { min }\end{array}$} \\
\hline & $\mathrm{R}_{\mathrm{t}}(\min )$ & Conc. & $\mathrm{R}_{\mathrm{t}}(\min )$ & Conc. & $\mathrm{R}_{\mathrm{t}}(\min )$ & Conc. & $\mathrm{R}_{\mathrm{t}}(\mathrm{min})$ & Conc. \\
\hline Fraction $\mathrm{C}_{3} \mathrm{~F}_{2}$ & - & - & 8.30 & 0.0034 & 12.30 & 0.0013 & 15.70 & 0.0019 \\
\hline Fraction $\mathrm{C}_{4} \mathrm{~F}_{2}$ & 6.79 & 0.0093 & 8.34 & 0.0014 & 12.50 & 0.0043 & 15.85 & 0.0079 \\
\hline Fraction $\mathrm{C}_{5} \mathrm{~F}_{1}$ & 6.82 & 0.0035 & 8.30 & 0.028 & 12.56 & 0.004 & 15.92 & 0.0101 \\
\hline
\end{tabular}

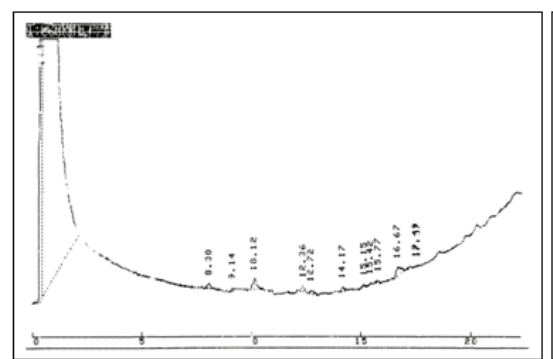

Fraction $\mathrm{C}_{3} \mathrm{~F}_{2}$

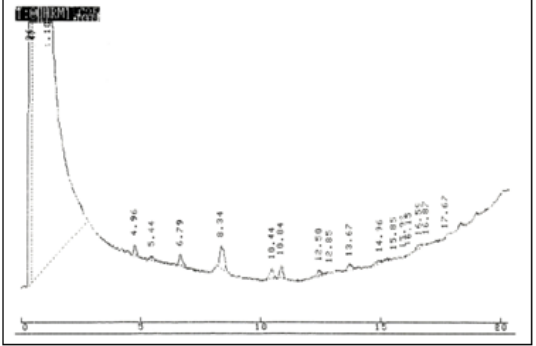

Fraction $\mathrm{C}_{4} \mathrm{~F}_{2}$

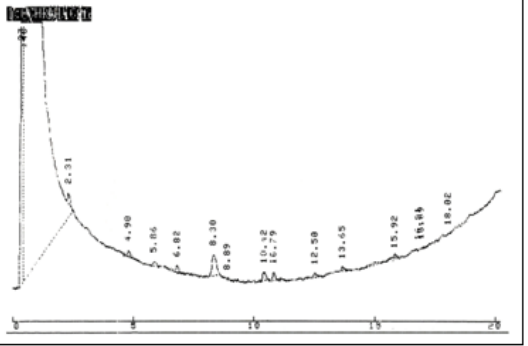

Fraction $\mathrm{C}_{5} \mathrm{~F}_{1}$

Fig. 1: GLC chromatograms of fatty acid compounds presented in Celosia cristata extracts.
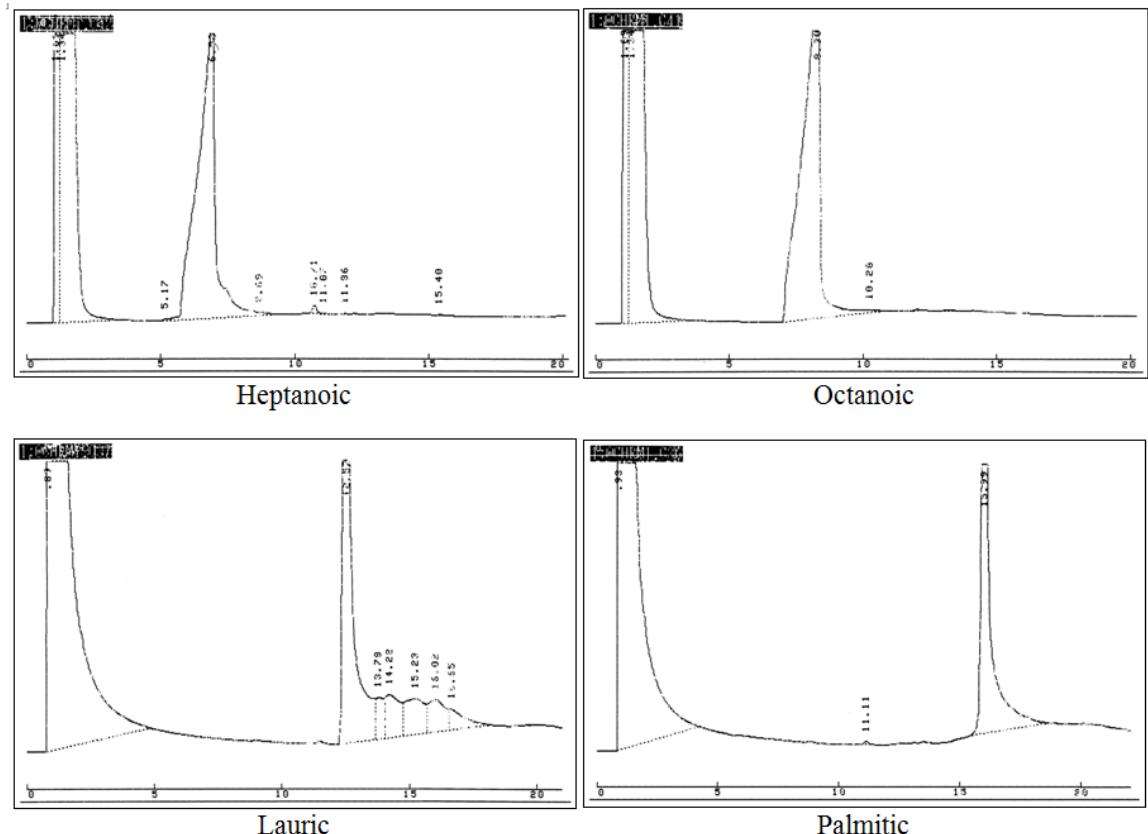

Fig. 2: GLC chromatograms of standard fatty acid compounds.

Table 2: HPLC analysis of Celosia cristata of phenolic compounds.

\begin{tabular}{|c|c|c|c|c|c|c|c|c|c|c|}
\hline \multirow[b]{4}{*}{ Sample } & \multicolumn{10}{|c|}{ Phenolic compound } \\
\hline & \multicolumn{2}{|c|}{ Hydroqunone } & \multicolumn{2}{|c|}{ p-Hydroxybenzoic acid } & \multicolumn{2}{|c|}{ Coumarin } & \multicolumn{2}{|c|}{ Salicylic acid } & \multicolumn{2}{|c|}{ Thymol } \\
\hline & \multicolumn{2}{|c|}{$2.530(\mathrm{~min})$} & \multicolumn{2}{|c|}{$2.801(\mathrm{~min})$} & \multicolumn{2}{|c|}{$3.235(\mathrm{~min})$} & \multicolumn{2}{|c|}{$2.507(\mathrm{~min})$} & \multicolumn{2}{|c|}{$3.602(\mathrm{~min})$} \\
\hline & $\mathrm{R}_{\mathrm{t}}(\mathrm{min})$ & Area $\%$ & $\mathrm{R}_{\mathrm{t}}(\min )$ & Area $\%$ & $\mathrm{R}_{\mathrm{t}}(\min )$ & Area \% & $\mathrm{R}_{\mathrm{t}}(\min )$ & Area \% & $\mathrm{R}_{\mathrm{t}}(\min )$ & Area \% \\
\hline Fraction $\mathrm{C}_{3} \mathrm{~F}_{3}$ & 2.486 & 47.780 & 2.863 & 22.693 & 3.103 & 15.957 & - & - & - & - \\
\hline Fraction $\mathrm{C}_{4} \mathrm{~F}_{3}$ & - & - & 2.853 & 50.640 & - & - & 2.403 & 49.360 & - & - \\
\hline Fraction $\mathrm{C}_{5} \mathrm{~F}_{2}$ & 2.502 & 62.111 & 2.813 & 31.293 & - & - & - & - & 3.571 & 6.596 \\
\hline Extract $\mathrm{C}_{4}$ & 2.595 & 37.914 & - & - & - & - & 2.402 & 50.520 & - & - \\
\hline
\end{tabular}

The table (3 and 4) and also images (1-10) were showed the antibacterial activity of Celosia cristata extracts against some pathogens bacteria (Staphylococcus aureus, Salmonella typhimurium and Escherichia coli).

All the fractions of the crude extracts of Celosia cristata which almost containing fatty acid and phenolic compounds gave antibacterial activity as compared with antibiotic compounds (Gentamicin (CN) 10 mceg, Ambkacin (AK) 10 meg, Tobramycin (TOB) 10 meg). Among the fatty acids which were presented in the (Chloroform-ethanol) fraction of a crude acetone extract $\left(\mathrm{C}_{3} \mathrm{~F}_{2}\right)$, fraction of a ethanol extract $\left(\mathrm{C}_{4} \mathrm{~F}_{2}\right)$, and fraction of aqueous extract $\left(\mathrm{C}_{5} \mathrm{~F}_{1}\right)$, was only found to exhibit strongest antibacterial activities against all the bacterial used under study. From the previous studies (Okpako and Ajibesin, 2015) which was used the leaf, 
Citation: Fatimah I. Sultan, Chromatographic Separation and Identification of Many Fatty acids and Phenolic Compounds from Flowers of Celosia cristata L. and Its Inhibitory Effect on Some Pathogenic Bacteria. Australian Journal of Basic and Applied Sciences, 12(7): 25-31.

steam, and also root extracts of Celosia argentea L. Amaranthaceae and his result was showed the antimicrobial effect on some groups of pathogenic bacteria within Pseudomonas aeurgenosa, Staph. aureusE. coli, Bacillussublilis, Candida albicans and Aspergillus niger.
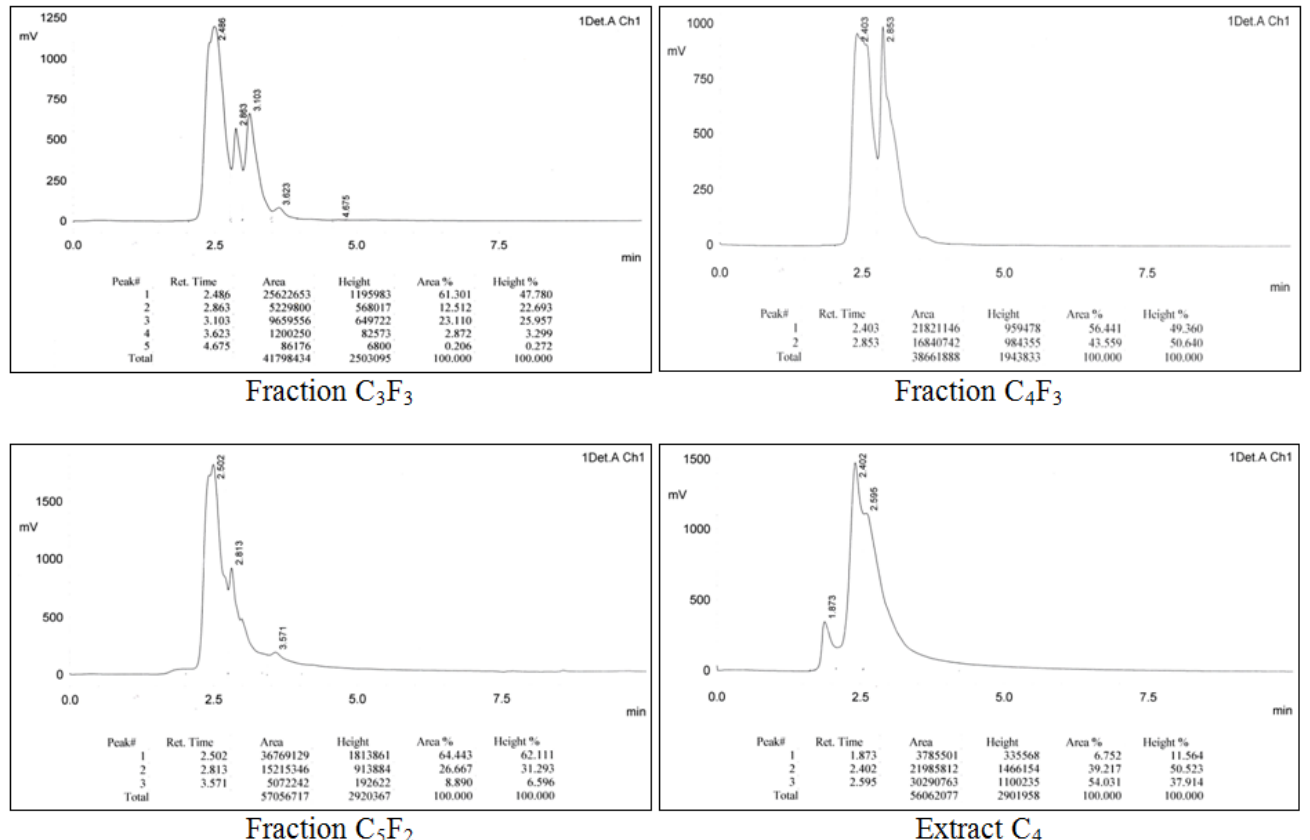

Extract $\mathrm{C}_{4}$

Fig. 3: HPLC analysis of phenolic compounds presented in Celosia cristata extract.
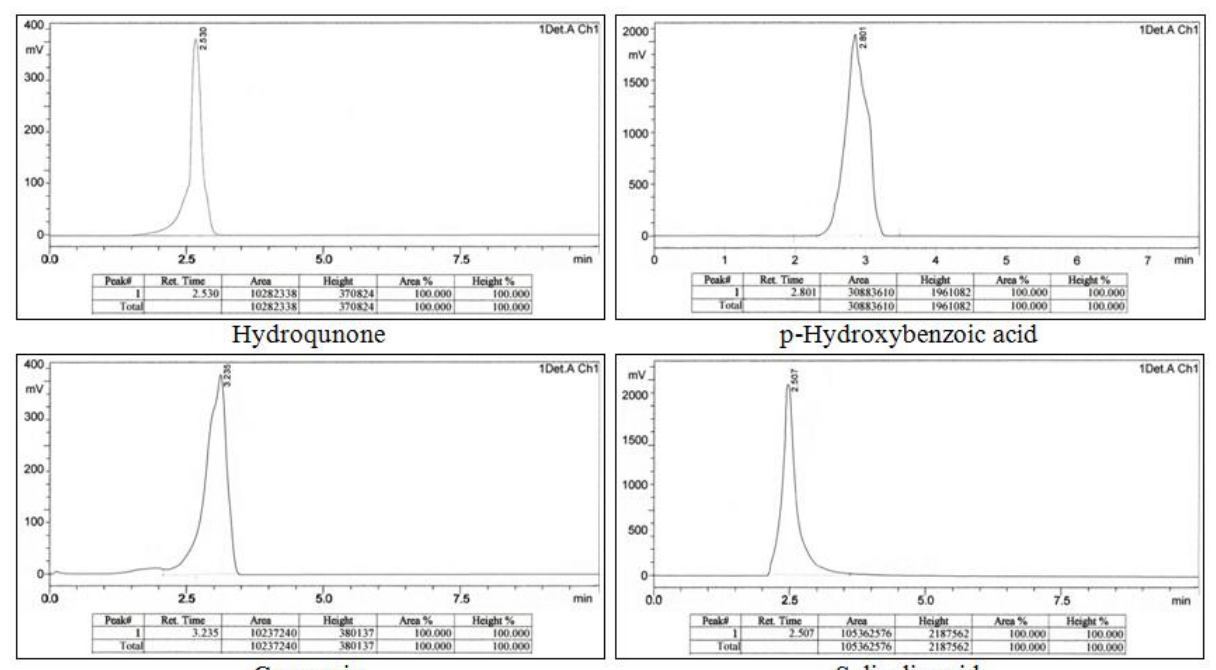

p-Hydroxybenzoic acio
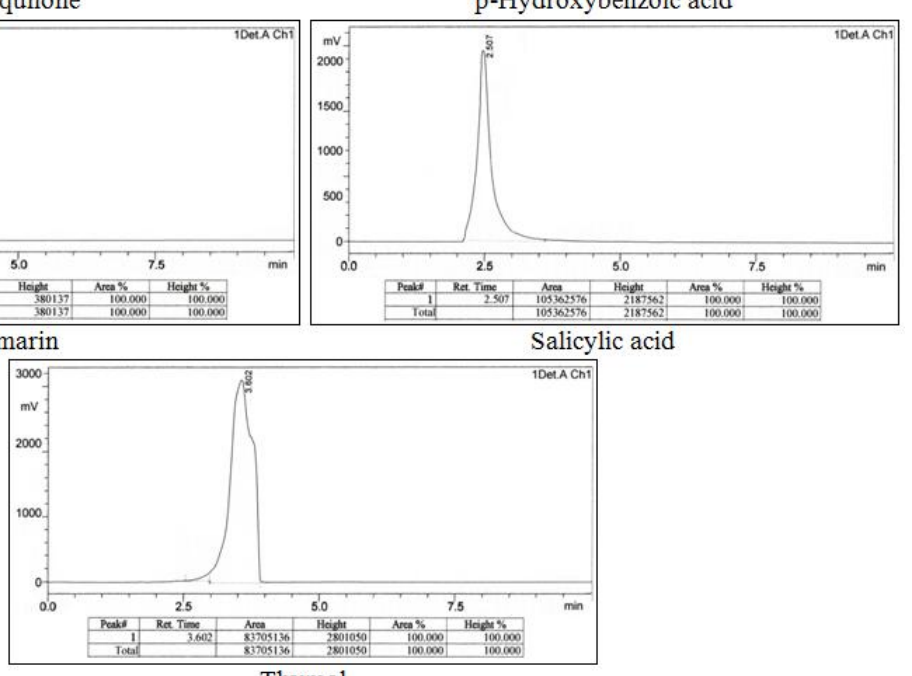

Thymol

Fig. 4: HPLC analysis of standard phenolic compounds.

Our interest is to note that the plant fraction extracts were able to inhibit the growth bacteria under study more than antibiotic that be used. Fatty acid in fractions $\mathrm{C}_{3} \mathrm{~F}_{2}$ and $\mathrm{C}_{5} \mathrm{~F}_{1}$ showed stronger antibacterial activity against the bacterial under study by increasing the fraction $\mathrm{C}_{4} \mathrm{~F}_{2}$. From the previous studies $(\mathrm{Al}-\mathrm{Snafi}$, 2015) were carried out of using groups of medicinal plants includes Celosia cristata L. This review was designed as a second part of medicinal plants with antimicrobial activity. In this study (Varadharaj and Muniyappan, 2017) was appeared which was used 3 types of celosia within cristata that was containing Alkaloids, Saponins, Tannins, Flavonoids, and also phenolic compounds were appeared antibacterial effect and anti-inflammatory. Moreover, these results revealed that the aqueous extract had higher significant anthelmintic activity than methanol extract. The preliminary phytochemical analysis on the extracts showed the presence of alkaloids, flavonoids, triterpenoids, phenolic compounds and tannins which might be responsible for the anthelimintic activity(Rubini, et $a l ., 2012$ ). The chemical constituents of Celosia cristata include mainly flavonoids and phenolic compounds which also used as antimicrobial activities (Indavani, et al., 2013). Celosia argentea L. have potential pharmacological values screened for its various pharmacological activities namely, anti-inflammatory, immunostimulatars, anticancer, hepatoprotective, antioxidant, wound healing antidiabetic and antibacterial activities which are reported in the extracts of different parts and phytoconstituents of this plant (Nidavani, et al., 2014). 
Citation: Fatimah I. Sultan, Chromatographic Separation and Identification of Many Fatty acids and Phenolic Compounds from Flowers of Celosia cristata L. and Its Inhibitory Effect on Some Pathogenic Bacteria. Australian Journal of Basic and Applied Sciences, 12(7): 25-31.

Phenolic compounds isolated from the Celosia cristata gave high antibacterial activities compared with antibiotic compounds under study against Salmonella typhimurium, Staph. aureus more than Escherichia coli (Table 4).

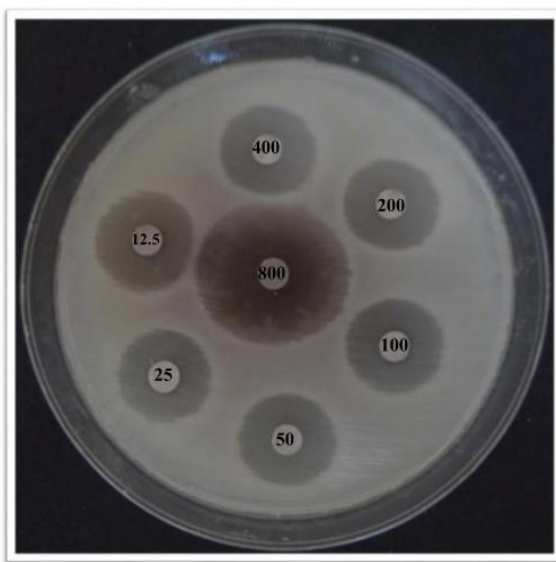

(1) Effect of $\mathrm{C}_{3} \mathrm{~F}_{2}$ on Staph. aureus

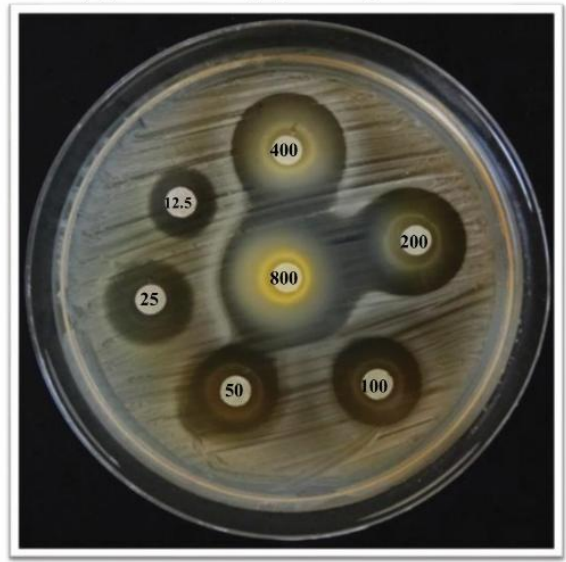

(3) Effect of $\mathrm{C}_{5} \mathrm{~F}_{1}$ on $E$. coli

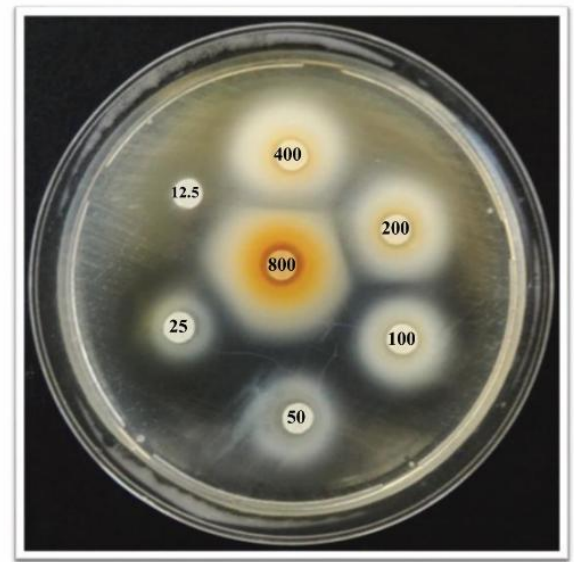

(2) Effect of $\mathrm{C}_{4} \mathrm{~F}_{2}$ on Salmonella typhimurium

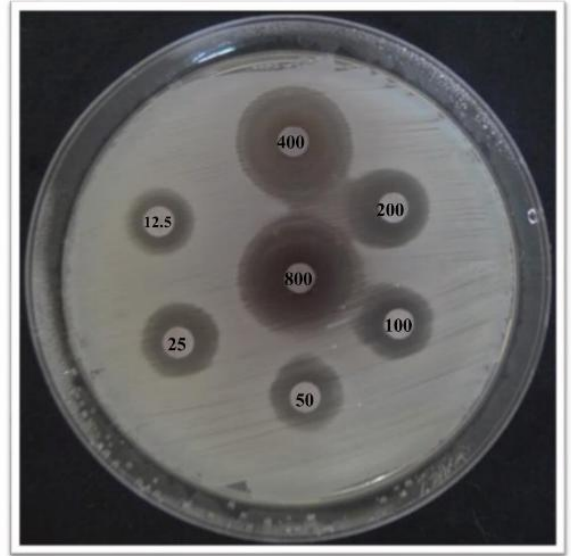

(4) Effect of $\mathrm{C}_{4} \mathrm{~F}_{2}$ on Staph. aureus

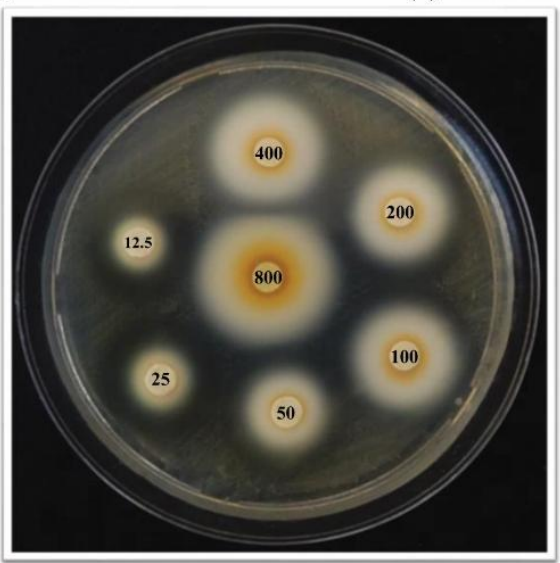

(5) Effect of $\mathrm{C}_{5} \mathrm{~F}_{1}$ on Salmonella typhimurium

Images (1-5): Antibacterial activity of some fatty acids in Celosia cristata extracts on bacteria under study.

Table 3: Antibacterial activity of separated fatty acids of Celosia cristata in some pathogenic bacteria ( $\mathrm{mm})$.

\begin{tabular}{|c|c|c|c|c|c|c|c|c|}
\hline \multirow[t]{2}{*}{ Microbial species } & \multirow{2}{*}{$\begin{array}{l}\text { Type of fatty acids } \\
\text { extracts }\end{array}$} & \multicolumn{7}{|c|}{ Concentration of extracts $\left(\mathrm{mg} / \mathrm{c}^{3}\right)$} \\
\hline & & 800 & 400 & 200 & 100 & 50 & 25 & 12.5 \\
\hline \multirow[t]{3}{*}{ Staphylococcus aureus } & $\mathrm{C}_{3} \mathrm{~F}_{2}$ & 25 & 15 & 14 & 14 & 13 & 12 & 12 \\
\hline & $\mathrm{C}_{4} \mathrm{~F}_{2}$ & 21 & 20 & 15 & 14 & 13 & 13 & 12 \\
\hline & $\mathrm{C}_{5} \mathrm{~F}_{1}$ & 26 & 23 & 20 & 17 & 15 & 12 & 13 \\
\hline \multirow[t]{3}{*}{ Salmonella typhimurium } & $\mathrm{C}_{3} \mathrm{~F}_{2}$ & 23 & 18 & 20 & 21 & 18 & 14 & 12 \\
\hline & $\mathrm{C}_{4} \mathrm{~F}_{2}$ & 20 & 18 & 15 & 14 & 12 & 11 & - \\
\hline & $\mathrm{C}_{5} \mathrm{~F}_{1}$ & 23 & 20 & 16 & 15 & 14 & 10 & 9 \\
\hline Escherichia coli & $\mathrm{C}_{3} \mathrm{~F}_{2}$ & 23 & 22 & 15 & 15 & 14 & 13 & 12 \\
\hline
\end{tabular}


Citation: Fatimah I. Sultan, Chromatographic Separation and Identification of Many Fatty acids and Phenolic Compounds from Flowers of Celosia cristata L. and Its Inhibitory Effect on Some Pathogenic Bacteria. Australian Journal of Basic and Applied Sciences, 12(7): 25-31.

\begin{tabular}{|l|l|l|l|l|l|l|l|l|}
\hline & $\mathrm{C}_{4} \mathrm{~F}_{2}$ & 20 & 18 & 18 & 17 & 17 & 15 & 11 \\
$\mathrm{C}_{5} \mathrm{~F}_{1}$ & 25 & 20 & 18 & 15 & 14 & 13 & 12 \\
\hline
\end{tabular}

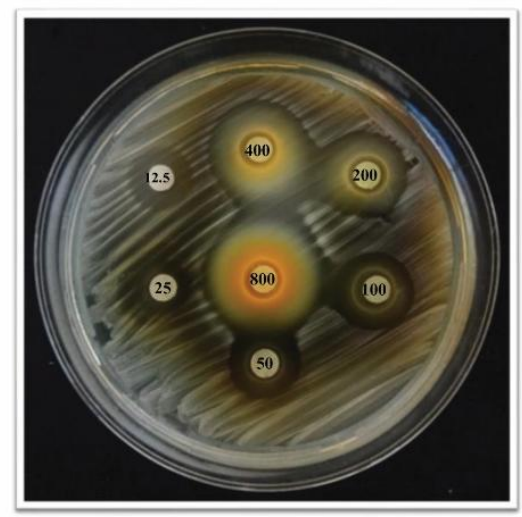

(6) Effect of $\mathrm{C}_{4} \mathrm{~F}_{2}$ on Staph. aureus

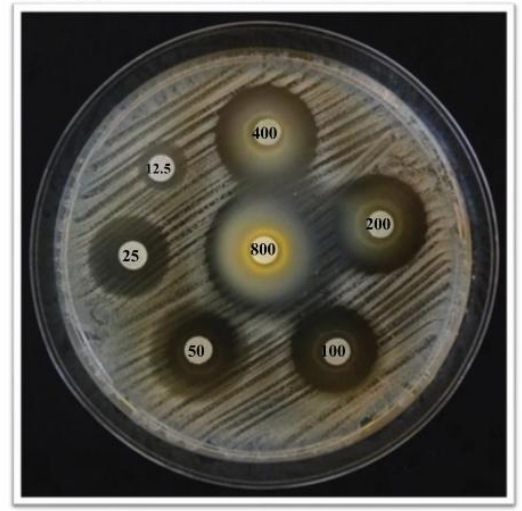

(8) Effect of $\mathrm{C}_{3} \mathrm{~F}_{3}$ on Salmonella typhimurium

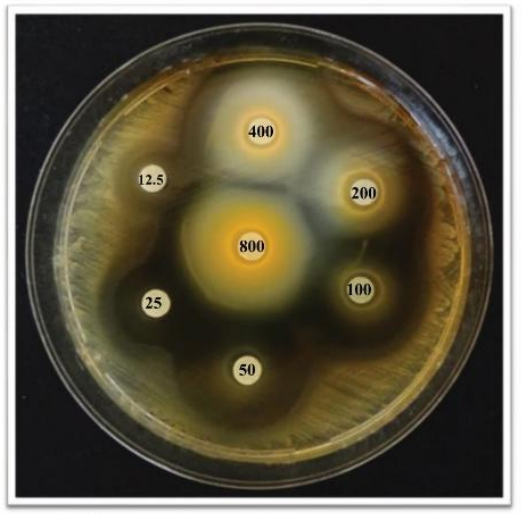

(7) Effect of $\mathrm{C}_{5} \mathrm{~F}_{2}$ on Staph. aureus

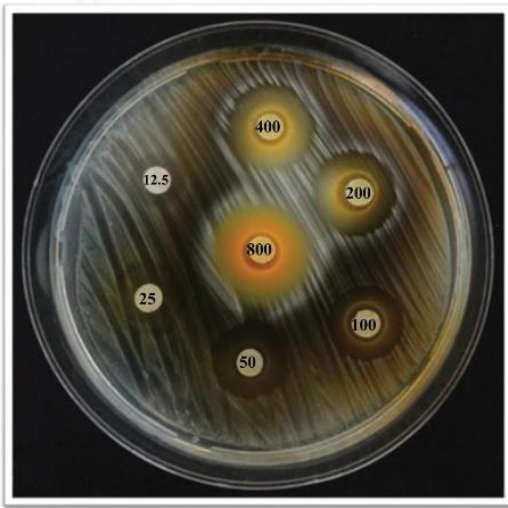

(9) Effect of $\mathrm{C}_{3} \mathrm{~F}_{3}$ on E. coli

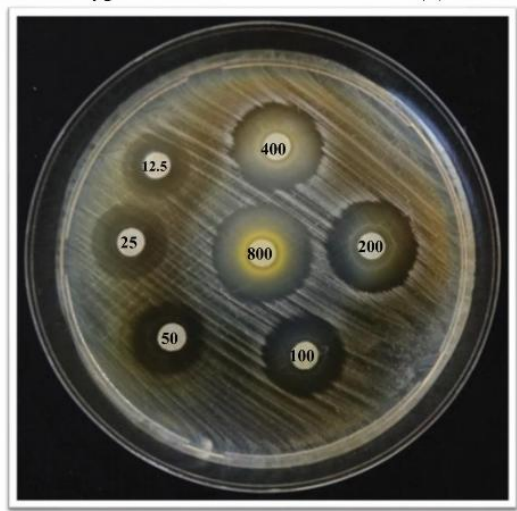

(10) Effect of $\mathrm{C}_{4} \mathrm{~F}_{3}$ on E. coli

Images (6-10): Antibacterial activity of some phenolic compounds in Celosia cristata extracts on bacteria under study.

Table 4: Antibacterial activity of separated phenolic compounds of Celosia cristata in some pathogenic bacteria (mm).

\begin{tabular}{|c|c|c|c|c|c|c|c|c|}
\hline \multirow[t]{2}{*}{ Microbial species } & \multirow{2}{*}{$\begin{array}{l}\text { Type of phenolic } \\
\text { compound }\end{array}$} & \multicolumn{7}{|c|}{ Concentration of extracts $\left(\mathrm{mg} / \mathrm{c}^{3}\right)$} \\
\hline & & 800 & 400 & 200 & 100 & 50 & 25 & 12.5 \\
\hline \multirow[t]{3}{*}{ Staphylococcus aureus } & $\mathrm{C}_{3} \mathrm{~F}_{3}$ & 23 & 21 & 19 & 20 & 17 & 17 & 16 \\
\hline & $\mathrm{C}_{4} \mathrm{~F}_{3}$ & 25 & 21 & 15 & 13 & 12 & 11 & 11 \\
\hline & $\mathrm{C}_{5} \mathrm{~F}_{2}$ & 27 & 23 & 21 & 18 & 17 & 15 & 12 \\
\hline \multirow[t]{3}{*}{ Salmonella typhimurium } & $\mathrm{C}_{3} \mathrm{~F}_{3}$ & 22 & 17 & 16 & 15 & 14 & 13 & 10 \\
\hline & $\mathrm{C}_{4} \mathrm{~F}_{3}$ & 20 & 18 & 16 & 13 & 11 & 10 & - \\
\hline & $\mathrm{C}_{5} \mathrm{~F}_{2}$ & 18 & 20 & 19 & 16 & 18 & 10 & 9 \\
\hline \multirow[t]{2}{*}{ Escherichia coli } & $\mathrm{C}_{3} \mathrm{~F}_{3}$ & 23 & 20 & 16 & 15 & 14 & 13 & 10 \\
\hline & $\mathrm{C}_{4} \mathrm{~F}_{3}$ & 19 & 18 & 17 & 16 & 16 & 15 & 10 \\
\hline
\end{tabular}


Citation: Fatimah I. Sultan, Chromatographic Separation and Identification of Many Fatty acids and Phenolic Compounds from Flowers of Celosia cristata L. and Its Inhibitory Effect on Some Pathogenic Bacteria. Australian Journal of Basic and Applied Sciences, 12(7): 25-31.

\begin{tabular}{|l|l|l|l|l|l|l|l|l|}
\hline & $\mathrm{C}_{5} \mathrm{~F}_{2}$ & 17 & 15 & 17 & 18 & 18 & 16 & 12 \\
\hline
\end{tabular}

Table 5: Antibacterial activity inhibition zone ( $\mathrm{mm})$ using the standard antibiotics.

\begin{tabular}{|l|l|l|l|}
\hline Bacteria & Gram positive & \multicolumn{2}{|l|}{ Salmonella typhimurium } \\
\cline { 2 - 4 } Antibiotics & Staphylococcus aureus & & \\
\hline Gentamicin (CN) $10 \mathrm{meg}$ & 7 & 15 & 10 \\
\hline Amikacin (Ak) $10 \mathrm{meg}$ & 16 & 16 & 14 \\
\hline Tobramycin (TOB) $10 \mathrm{meg}$ & 8 & 20 & 11 \\
\hline
\end{tabular}

\section{REFERENCES} 53.

Adam, P.O., 2006. Antibacterial activity of aqueous and ethanol extracts of the stem bark of Alsonia boonei and Morinda lucida. Sci. Res. Essaya, 1(2): 50-

Al-Kaisy, M.T., H.A. Hadwan, H.M. Saleh and A.K. Hussen, 1991. Determination of citric and oxalic acids in fermented solutions of Aspergillus niger by gas-liquid chromatography. Iraqi: J. Microbiol., 3: 170-177. 261.

Al-Snafi, A.E., 2015. The chemical constituents and pharmacological importance of Celosia cristata. A-A Review. J. of Pharmaceutical Biology, 5(4): 254-

Aruther I. Vogel, 1972. Practical organic chemistry including qualitative organic analysis $3^{\text {rd }}$ edition, 445.

Asif, M., 2011. Health effects of omega 3.6.9 fatty acids: perilla frutesceus is a good example of plant oil orient oharm. Exp. Med., 11(1): 51-59.

Balasubrahmanyam, A., V.K. Baranwal, M.L. Lodha, A. Varma and H.C. Kapoor, 2000. Purification and properties of growth stage-dependent antiviral proteins from the leaves of Celosia cristata, Plant Science, 154: 13-21.

Bauer, A.W., W.M.M. Kirby, J.C. Sherns and M. Turch, 1966. Antibiotic susceptibility testing by a standardized single disc method. Am. J. Clin. Pathol., 45: 493-496.

Cai, Y., M. Sun and H. Cork 2003. Antioxidant Activity of $\beta$-lains from plants of the Amaranhaceae. J. of Agriculture and Food Chemistry, 51: $2288-2294$.

Fitoussi, R., D. Esteve, A.S. Delassus and K. Vie, 2013. Impact of Celosia cristata extract on adipogenesis of native human CD 34t/CD31- Cells J. of Cometics Dermatological Sciences and Apllications, 3: 55-63.

Harborne, J.B., 1998. Phytochemical Methods, London: Chapman and Hall, 60-66.

Indavani, R.B., A.M. Mahalkshmi and Mallappa Shalawadi, 2013. Towards a better understanding of an updated ethnopharmacology of Celosia Argentea L. International Journal of pharmacy and pharmaceutical Sciences, 5(3): 0975-1491.

Jayanthy, V. and A. Shafna, 2012. Use of flowers as antimelanocyte agent against UV radiation effects. American J. of Biopharm Biochem and Life Sci., 1(1): A 068.

John, P.B. and K.K. Denis, 1980. Biochemistry of ungerminated and germinated spores of the vesicular arbuscular mycorrhizal fungus, Glomas Caledonius:

Changes in meutral and polar lipids. J. of Lipid Research, 21: 739-750.

Nidavani, R.B., A.M. Mahalakshmi, M. Seema and K.L. Krishna, 2014. Pharmacology of Celosia Argentea L. J. Atoms and Molecules, 4(1): 635-644.

Okpako, E. and K.K. Ajibesin, 2015. Antimicrobial Activity of Celosia argentea L. Amarathaceae. American Journal of Research Communication, 3(5).

Rubini, D., D. Sudhahar and K. Anandarajagopal, 2012. Phytochemical investigation and anthelmintic activity of Celosia cristata Leaf extract. International Research. J. of Pharmacy, IRJP 3(5): ISSN 2230-8407.

Surse, S.N., B. Shrivastava, P. Sharma, P.S. Gide and Sana Attar, 2013. Celosia cristata: Potent pharmacotherapeutic Herb-A review. International J. of pharmaceutical and phytopharmacological Research (eljPPR).

Surse, S.N., B. Shrivastava, P. Sharma, J. Sharma and P.S. Gide, 2014. "Pharmacognostic Standardisation of whole plant of Celosia argentea, Var. cristata

(L). International. J-for Pharmaceutical Research Scholars (IJPRS), 3: 1-3.

Varadharaj, V. and J. Muniyappan, 2017. Phytochemical and phytotherapeutic properties of Celosia species - A Review international J. of Pharmacognosy and phytochemical Research, 9(6): 820-825.

Xiang C., M. Guo, H. Song and C. Yadan, 2010. Study on chemical constituents of Celosia cristata seed, 32(6): 657-660.

Yun, S.M., B.H. Chei, H.O. Ku, M.H. Lee, H.M. Nam, K.J. Lee, S.W. Park, H.J. Jang and S.W. Son, 2008. Antimicrobial activities of the flower extract of Celosia cristata L. Planta Med., 74: PA31. 